\title{
Renewable source of energy demands through production of bio-gas from vegetable and food waste
}

\author{
V.Jaiganesh
}

\begin{abstract}
The vegetable waste generated day by day for every households are increasing gradually. The Vegetable waste can be utilized for biomethanation process which is nothing but anaerobic digestion using bio gas plant. The bio gas plant is easy to manufacture by simple technique. It needs minimum cost investment and same can be utilized for every household. The vegetable waste, fruits waste and food waste can also be the part of a biomethanation process inputs. The gas produced by the plant is sufficient for a family of three to four for cooking and other utilization. The bio gas is renewable source and also called as gobar gas. In rural india the daily manure are still used as feed stock for biogas plants called "Gobar gas" for daily usage for a long period of time.
\end{abstract}

Keywords: Anaerobic Digestion, Biogas, Energy, Vegetable waste, Fertilizers

\section{INTRODUCTION}

The biogas is a mixture of gases that is produced by the breakdown of organic matter and consists of methane and other particles constituents mostly in the absence of oxygen. The gas normally produced from raw materials such as agricultural waste, food waste and manure so as to get the anaerobic digestion with methanogen or organisms [1]. In general this system is known as anaerobic digester or a bio reactor or digestor. The biogas is nothing but methane $\left(\mathrm{CH}_{4}\right)$ and carbon monoxide $\left(\mathrm{CO}_{2}\right)$ combusted with oxygen. The gas can be used as a fuel for heating purpose such as cooking and also for used to convert the energy for electricity [2].

The development of sustainable solution on renewable energy to satisfy the energy demands [3]. The renewable energy developed must not have any severe adverse effects on environment safety. The materials that produce these types of energy requirements are readily available and must be cheaper in cost of production. Enviromentally acceptable waste which is produced already must be used appropriately for soil protection and also must be used for fertilizer to the plants growth [4]. The biogas plant is the conventional process that is used for generating the biogas as well as used for produce a fertilizer for the landfill. The biogas that can be produced on the decomposition of vegetable and food waste is composed of methane, carbon dioxide and impurities like hydrogen and some nitrogen [5].

The methane production and the anaerobic digestion of degradable organic matter is depends on the amount and kind of material that added to the digester system. The leftover foods and vegetable wastes with manure for anaerobic

Revised Manuscript Received on 14, October 2019.

Dr.V.Jaiganesh, Professor Department of Mechanical Engineering, Academy of Maritime Education and Research, Kanathur, Chennai, Tamilnadu, India. (Email: jaiganeshresearch@ametuniv.ac.in) digester are subjected to energy production in different ways. There are many digestive system that are available for the present day usage, like single phase, double or two phase digestion and fry fermentation system. The co digestion system is also a special king of digestion system that employs the positive results on improving the performance of the digestion. The improvement takes place on digestion medium and supply of nutrients for microorganisms [6].

\section{BIOGAS PROJECT PLANT}

LPG (Liquefied Petroleum Gas) used in urban part of India and its prices are increasing day by day along with the global price increase. The only alternate solution is usage of biogas as cooking fuel even on urban areas. The small scale digestion facility has been already in usage in the countries like India, Nepal and Bangladesh where biogas is produced from the anaerobic digester and popularly known as gobar gas. An airtight circular vessel consists of a vegetable waste and food waste with cow dung used for operating the digester. A pipe connection at the top most part is used for fuel system and the middle one is to remove the manure in the form of liquid which will be discharged all the time when gas produces on the digester is shown in figure 1.

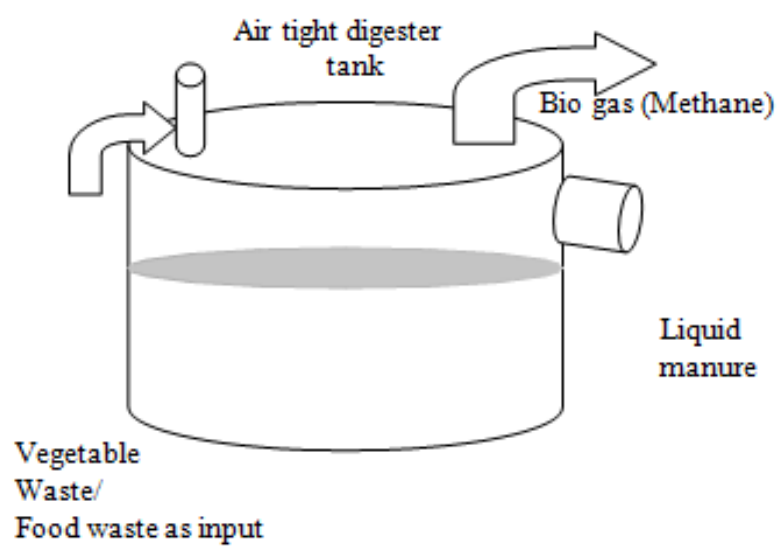

Figure .1 Bio gas generator system

The sintex tank is normally used for the simple digester plant for home made biogas plant. The bio gas generator consists of simple pipeline connection for methane gas for release.

\section{BIOGAS COMPOSITION AND UTILIZATION \& RESULTS}

The biogas composition of different compounds and their percentage of use are shown in Table.1.

Published By: 
The composition depends on substrate concentration, temperature and $\mathrm{pH}$ value [7]. The biogas production depends upon the waste treatment of plants and the technology that used [8]. The average methane concentration may goes upto $75 \%$ methane production and also increased upto $80-90 \%$ with some advanced gas purification techniques [9].

Table: 1 Composition of biogas

\begin{tabular}{|l|l|l|}
\hline Compound & Formula & \% \\
\hline Methane & $\mathrm{CH}_{4}$ & $50-75$ \\
\hline Carbon dioxide & $\mathrm{CO}_{2}$ & $25-50$ \\
\hline Nitrogen & $\mathrm{N}_{2}$ & $0-10$ \\
\hline Hydrogen & $\mathrm{H}_{2}$ & $0-1$ \\
\hline $\begin{array}{c}\text { Hydrogen } \\
\text { sulfide }\end{array}$ & $\mathrm{H}_{2} \mathrm{~S}$ & $0.1-0.5$ \\
\hline Oxygen & $\mathrm{O}_{2}$ & $0-0$. \\
\hline
\end{tabular}

\section{CONCLUSION}

It is observed that the total leftover food from each household in India is increasing day by day and the vegetable waste is also increased every day. The alternate solution for the energy requirements for fuel usage is through biogas or the renewable sources of energy alone. The current study emphasis on the average biogas composition production by vegetable and food waste generated everyday in India is increased gradually. The food and vegetable waste mixed with manure and can be used as organic fertilizer. Through the use of renewable source of technology we can reduce the green house effects and makes the world into pollution free nations.

\section{ACKNOWLEDGMENT}

I thank the Academy of Maritime Education and Training (Deemed to be University), kanathur, Chennai, India, for providing the necessary support for publication.

\section{REFERENCES}

1 National Non-Food Crops Centre. "NNFCC Renewable Fuels and Energy Factsheet: Anaerobic Digestion", Retrieved on 2011-02-16.

2 "Biogas \& Engines"., www.clarke-energy.com. Retrieved 21 November 2011.Hafner, Sasha, "Predicting methane and biogas production with the biogas package" (PDF). CRAN, 2017.

3 Lohri, C. Research on anaerobic digestion of organic solid waste at household level in Dares Salaam, Tanzania; Bachelor Thesis at ZHAW (Zurich University of Applied Sciences) in collaboration with Eawag (Swiss Federal Institute of Aquatic Science andTechnology). 2009.

4 Heb, F. Decentralised Anaerobic Digestion of Market Waste - A Case Study inThiruvananthapuram, India. Sandec Report. 2009.

5 Chanakya, H.N.; Ramachandra, T.V.; Vijagachamundeeswari, M. Anaerobic digestion and reuse of digested products of selected products of urban solid waste, 2006.

6 "Juniper". Archived from the original on 30 April 2015 Retrieved 15 May 2015.

7 Richards, B.; Herndon, F. G.; Jewell, W. J.; Cummings, R. J.; White, T. E., "In situ methane enrichment in methanogenic energy crop digesters". Biomass and Bioenergy. 6 (4): 275-282, 1994.
8 Leta Deressa, Solomon Libsu , R. B. Chavan , Daniel Manaye and Anbessa Dabassa, "Production of Biogas from Fruit and Vegetable Wastes Mixed with Different Wastes", Environment and Ecology Research 3(3): 65-71, 2015.

\section{AUTHOR PROFILE}

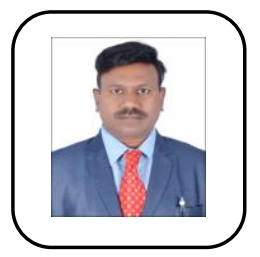

Dr. Jaiganesh Venu is currently working as a Professor in Mechanical Engineering Department at AMET, Chennai.

His previous employment is with G.S Moze College of Engineering as HOD-Mech, Pune, Maharashtra. He was the Research and Development Head (R\&D) of S A Engineering College, (Chennai, Tamilnadu) from 2011- 2018 for 6.5 years and the Head of the Department of Mechanical Engineering at Sri Ram Engineering College from 2010-2011. He graduated Production Engineering from University of Madras (First Class), completed his ME(Ind.Engg) from NIT Tirchy (First Class) \& PhD from Anna University Chennai, Tamilnadu, India, all in Mechanical Engineering.

Dr. Ganesh has done extensive research work in the area of Material Joining (Friction Stir Welding and Stir Processing. He has published over 30 research papers in International Journals and 45 Papers Published in Conferences of repute, has successfully completed 1 research project under the RPS Scheme of Rs.13 Lakhs from AICTE, and 5 sponsored national seminar and conferences. He has filed 6 patents to his credit and 2 published already. He is also a reviewer of reputed journals in his field. Dr. Ganesh interested in the field of Eco Friendly Welding Techniques, Sustainable technology, Composite, Evolutionary optimization and Manufacturing Energy Management.

$\mathrm{He}$ is the author of the text book 'Friction Stir Welding of Dissimilar $\mathrm{Mg}$ Alloys ' (2017), by LAMBERT Academic Publishing, Verlag Publisher, with ISSNNo. 978-3-330-34854-7 and published 4 chapters from reputed Indian publication. Dr. Ganesh received the Certificate of Excellence Award(2013), EET CRS Technology Achievement Awards \& Mahatma Gandhi Gold Medal Award for excellence'(2014) for Outstanding individual achievement in Education from Global Economic Progress \& Research Association (GEPRA), New Delhi, \& Outstanding Faculty Award(2015), from Venus International Foundation \&Best Academic Researcher Award (2015) ASDF Global Awards , \& Best Professor Award(2016), ASDF \& Research Excellence Award(2017),Institute for Exploring Advances in Science \& Engineering-IEAE \&Best Supervisor Award (2017),International Society for Scientific Research and Development -ISSRD. Innovative Scientific Research \& Dedicated Professor (Mechanical Engg) award in 2018 , Malaysia. He is also a certified Chartered Engineer from IEI Kolkata and Member of ISTE and IEI.

Dr. Ganesh is the Editorial Board Member and Journal Reviewer for many reputed journals with high impact factor including the Renewable and Sustainable Energy Reviews, Materials Design and Environmental Progress \& Sustainable Energy, Elsevier publishers. Dr. Ganesh is the recognized Supervisor for many universities and presently guiding 11 scholars and completed 3 Ph.D's. Dr.Ganesh, Telecasted the Technical Talk in the topics like"ECO Friendly FSW Welding" and "ECO -E-Bike " talks in the Program Called "Seekaram Thodu" in Vasanth TV, and the Program called SUU in Makkal TV, Vanamvasappadum in Jaya TV. Dr.Ganesh Visited countries like Bangkok, Thailand, Combodia, Malaysia and Singapore for his research discussion and for Paper Presentation in prestigious universities like NUS and NTU and has interacted with Professors and technical experts

in his field of interest. Knowledge about preparing the documents for NBA, NAAC, NIRF, I-G Quest (QS rankings). 